\title{
Peramalan Tingkat Penghunian Tempat Tidur Hotel Bintang Tiga di Kota Surakarta dengan Metode Autoregressive Integrated Moving Average (ARIMA)
}

\author{
Shindy Dwi Pratiwi ${ }^{1}$ \\ ${ }^{1}$ Program Studi Statistika, Universitas Sebelas Maret \\ shindy.dwi.pratiwi@gmail.com
}

\begin{abstract}
Surakarta is a cultural city that is now starting to attract domestic and foreign tourists. This makes many tourists visit the city of Surakarta so that it affects the occupancy rate of hotels in Surakarta. The occupancy rate of hotels in Surakarta has fluctuations from each year. The uncertainty of hotel occupancy rates in Surakarta will certainly affect investors to choose policies in the hotel industry so that hotel occupancy rates in Surakarta City need to be estimated for the next year. In this study, the Autoregressive Integrated Moving Average (ARIMA) method was used to forecast hotel occupancy rates in Surakarta from January to May 2018. By using the best model IMA (1.1), it was concluded that the occupancy rate of threestar Surakarta hotels increased every the month.
\end{abstract}

Keywords : occupancy rate of hotel, forecasting, ARIMA.

\section{Pendahuluan}

Kota Surakarta merupakan kota budaya yang kini mulai diminati oleh wisatawan domestik maupun asing. Jumlah wisatawan di Kota Surakarta tahun 2017 mencapai 3.069.597 wisatawan baik wisatawan domestik maupun asing. Jumlah wisatawan berpengaruh terhadap tingkat hunian hotel Kota Surakarta. Pada Desember 2017 tingkat hunian hotel mencapai 72,36 \% [1]. Hal ini mengalami peningkatan dibandingkan dengan bulan Desember 2016 yang mencapai 70,62\%. Namun pada bulan Juni 2017, tingkat hunian hotel mengalami penurunan yang signifikan dari bulan sebelumnya yaitu hanya $51,18 \%$ dengan penurunan mencapai 5,5\%. Jika dibandingkan dengan bulan Juni 2016, tingkat hunian hotel bulan Juni 2017 mengalami kenaikan sebesar 1,68\%. Ketidakpastian tingkat hunian hotel di Kota Surakarta tentunya akan mempengaruhi para investor untuk memilih kebijakan dalam industri perhotelan di Kota Surakarta. Oleh karena itu, diperlukan adanya peramalan untuk tingkat hunian hotel di Kota Surakarta, salah satunya adalah hotel bintang tiga Kota Surakarta. Salah satu metode untuk meramalkan tingkat hunian hotel bintang tiga di Kota Surakarta adalah metode ARIMA.

\section{Landasan Teori}

2.1. Pengertian Hotel. Hotel berasal dari Bahasa Latin yakni "hospes" yang mempunyai pengertian untuk menunjukkan orang asing yang menginap di rumah seseorang kemudian berkembangnya menjadi kata "hotel" yang dinyatakan sebagai 
rumah penginapan. Hotel adalah suatu usaha yang bergerak di bidang akomodasi yang dikelola secara professional guna menghasilkan keuntungan dengan menyediakan pelayanan penginapan, makanan, minuman, dan fasilitas yang lain [2]. Ciri khusus dari hotel adalah mempunyai restoran baik dikelola langsung oleh manajemen hotel maupun oleh pihak lain. Klasifikasi hotel berdasarkan bintang dibedakan menjadi hotel bintang satu, bintang dua, bintang tiga, bintang empat, dan bintang lima.

2.2. Pengertian Tingkat Hunian Tempat Tidur. Tingkat hunian tempat tidur menyatakan suatu keadaan sampai sejauh mana jumlah tempat tidur terjual jika dibandingkan dengan seluruh jumlah tempat tidur yang mampu untuk dijual [3]. Occupancy ratio merupakan tolok ukur keberhasilan hotel dalam menjual produk utamanya yaitu tempat tidur.

\subsection{Pengertian Autoregressive Integrated Moving Average (ARIMA). Metode}

ARIMA disebut juga sebagai metode Box-Jenkins. ARIMA merupakan suatu metode yang menghasilkan ramalan-ramalan berdasarkan sintesis dari pola data secara historis [4]. Metode ARIMA tidak dapat digunakan untuk peramalan jangka panjang karena hasil ramalannya cenderung tetap. Model ARIMA dilambangkan dengan ARIMA ( $\mathrm{p}, \mathrm{d}, \mathrm{q})$ dimana $\mathrm{p}$ menunjukkan orde AR (Autoregressive), d menunjukkan difference, dan q menunjukkan orde MA (Moving Average). Sebelum memodelkan ARIMA perlu dilakukan uji kestasioneran data.

2.4. Uji Kestasioneran Data. Stasioneritas berarti bahwa tidak terjadinya pertumbuhan dan penurunan data. Suatu data dapat dikatakan stasioner apabila pola data tersebut berada pada kesetimbangan disekitar nilai rata-rata yang konstan dan variansi disekitar rata-rata tersebut konstan selama waktu tertentu [5]. Data time series dikatakan stasioner apabila tidak ada unsur trend dalam data dan tidak ada unsur musiman atau ratarata dan variannya tetap. Stasioner juga dapat dilihat dari plot Autocorrelation Function (ACF) data tersebut. Apabila plot ACF turun mendekati nol secara cepat, pada umumnya setelah lag kedua atau ketiga maka dapat dikatakan stasioner [6].

Data dikatakan nonstasioner apabila terdapat unsur trend dalam data, yaitu mengalami kenaikan dan penurunan seiring bertambahnya periode waktu. Pada data nonstasioner yang memiliki trend akan memiliki nilai ACF yang signifikan pada lag-lag awal kemudian mengecil secara bertahap.

Uji kestasioneritas data juga dapat dilakukan melalui uji Augmented Dickey Fuller (ADF). Menurut Tsay [7], hipotesis uji ADF adalah: 
$H_{0}: \emptyset=1$ (terdapat akar unit sehingga data runtun waktu tidak stasioner)

$H_{1}: \emptyset<1$ (tidak terdapat akar unit sehingga data runtun waktu stasioner)

Statistik uji ADF dirumuskan sebagai $t_{\text {hitung }}=\frac{\widehat{\emptyset}-1}{s d(\widehat{\emptyset})}$ dengan $\widehat{\emptyset}$ adalah estimasi parameter model autoregressive (AR) dan $s d(\bar{\emptyset})$ adalah standar deviasi dari estimasi parameter model AR. $H_{0}$ ditolak apabila $t_{\text {hitung }}$ kurang dari $t_{\alpha,(n-p)}$ atau p-value $<\alpha$ dengan $\alpha$ adalah tingkat signifikansi.

2.5. Differencing Data. Differencing (pembedaan) dilakukan untuk menstasionerkan data nonstasioner. Operator backward shift sangat tepat untuk menggambarkan proses differencing [5]. Penggunaan backward shift adalah sebagai berikut:

$B X_{t}=X_{t-1}$

dengan

$X_{t} \quad$ : nilai variabel X pada waktu ke-t

$X_{t-1} \quad$ : nilai variabel $X$ pada waktu ke-t-1

B : backward shift

Notasi B yang dipasang pada $\mathrm{X}$ mempunyai pengaruh menggeser data satu waktu ke belakang. Sebagai contoh, jika suatu data time series nonstasioner maka data tersebut dapat dibuat mendekati stasioner dengan melakukan differencing orde pertama dari data. Rumus untuk differencing orde pertama, yaitu:

$$
X_{t}^{\prime}=X_{t}-X_{t-1}
$$

dengan $X_{t}^{\prime}$ adalah nilai variabel $\mathrm{X}$ pada waktu ke-t setelah differencing. Dengan menggunakan backware shift, persamaan diatas diubah menjadi:

$$
X_{t}^{\prime}=X_{t}-B X_{t}
$$

atau

$$
X_{t}^{\prime}=(1-B) X_{t}
$$

dimana differencing pertama dinyatakan oleh 1-B.

2.6. Autocorrelation Function (ACF) dan Partial Autocorrelation Function (PACF). ACF dan PACF digunakan untuk mengidentifikasi model ARIMA. Moving 
Average (MA) diidentifikasi dengan menggunakan plot ACF sedangkan Autoregressive (AR) diidentifikasi dengan menggunakan plot PACF.

2.7. Model ARIMA. Model time series yang digunakan berdasarkan asumsi bahwa data time series tersebut stasioner, artinya rata-rata varian $\left(\sigma^{2}\right)$ suatu data time series konstan. Jika pola melalui proses differencing sebanyak d kali dapat dijadikan stasioner, maka pola itu dikatakan nonstasioner homogen tingkat $d$. Seringkali proses random stasioner tidak dapat dijelaskan dengan baik oleh model moving average saja atau autoregressive saja, karena proses tersebut mengandung keduanya. Karena itu, gabungan kedua model, yang dinamakan Autregressive Integrated Moving Average (ARIMA) dapat lebih efektif menjelaskan proses tersebut. Menurut Cryer [8] bentuk umum model ARIMA adalah:

$$
\begin{gathered}
Y_{t}=Y_{t-1} \emptyset_{1}\left(Y_{t-1}-Y_{t-2}\right)+\emptyset_{2}\left(Y_{t-2}-Y_{t-3}\right)+\cdots+\emptyset_{p}\left(Y_{t-p}-Y_{t-p-1}\right)+e_{t} \\
-\theta_{1} e_{t-1}-\theta_{2} e_{t-2}-\cdots-\theta_{q} e_{t-q}
\end{gathered}
$$

dengan

$Y_{t}$

: nilai variabel ke- $t$

$Y_{t-1}, \ldots, Y_{t-p-1} \quad$ : variabel bebas (nilai masa lalu time series)

$e_{t} \quad$ : residu pada waktu ke- $t$

$e_{t-q} \quad:$ residu model MA pada waktu ke-t- $q$

$\emptyset_{p} \quad$ : parameter model $\operatorname{AR}(p)$

$\theta_{q} \quad:$ parameter model MA $(q)$

Proses ARIMA dilambangkan dengan ARIMA $(p, d, q)$ dengan $q$ menunjukkan orde/ derajat Autoregressive (AR), $d$ menunjukkan tingkat proses differencing, dan $p$ menunjukkan orde/ derajat Moving Average (MA). Jika proses tidak mengandung Autoregressive, maka modelnya adalah Integrated Moving Average dan dilambangkan IMA $(d, q)$. Sedangkan jika proses tidak mengandung Moving Average, maka modelnya adalah Autoregressive Integrated dan dilambangkan ARI $(p, d)$. 
2.8. Uji Signifikansi Parameter dan Konstanta. Uji signifikansi parameter dan konstanta adalah

i. Hipotesis

$H_{0}$ : Parameter tidak signifikan $H_{0}$ : Konstanta tidak signifikan dalam model dalam model

$H_{1}$ : Parameter signifikan dalam model $\quad H_{1}$ : Konstanta signifikan dalam model

ii. Tingkat Signifikansi

$\alpha=0.05$

iii. Keputusan Uji

$H_{0}$ ditolak jika nilai- $p<\alpha$

iv. Statistik Uji

v. Kesimpulan

Apabila konstanta tidak signifikan, maka konstanta dikeluarkan dari model dan dilakukan kembali uji signifikansi parameter pada model dengan tidak melibatkan konstanta. Model yang dipilih adalah model yang mempunyai parameter signifikan, ditandai dengan nilai- $p<\alpha$ dan mempunyai nilai mean square error (MSE) terkecil.

2.9. Uji Diagnostik Model. Untuk mengetahui apakah model runtun waktu yang diperoleh baik untuk digunakan, maka dilakukan uji diagnostik model yang meliputi uji normalitas residu, uji independensi residu dan uji homogenitas residu.

a. Uji Homogenitas Residu

Uji homogenitas residu dapat dilakukan dengan uji Lagrange multiplier. Hipotesis dari uji Lagrange multiplier dapat dituliskan sebagai berikut:

i. Hipotesis

$$
H_{0}: \beta_{1}=\beta_{2}=\cdots=\beta_{m}=0 \quad \text { (tidak terdapat heterokesdastisitas sampai }
$$$$
\text { lag ke }-m)
$$

$H_{1}$ :paling tidak terdapat satu $\beta_{i} \neq 0$ untuk $i=1,2,3, \ldots, m \quad$ (terdapat heterokesdastisitas sampai lag ke $-m$ )

ii. Tingkat signifikansi $=0,05$

iii. Daerah kritis : $H_{0}$ ditolak jika $\xi>\chi_{k}^{2}$ atau nilai- $p<\alpha$

iv. Statistik uji

$\xi=T R^{2}$

dengan 


$$
\begin{aligned}
& T=\text { ukuran sampel } \\
& R^{2}=\text { koefisien determinasi }
\end{aligned}
$$

\section{b. Uji Normalitas Residu}

Uji kenormalan model dilakukan dengan uji Kolmogorov Smirnov dengan hipotesis awal $H_{0}$ : residu model berdistribusi normal dan $H_{1}$ :residu model tidak berdistribusi normal dengan tingkat signifikansi sebesar 0,05 keputusan tolak $H_{0}$ jika nilai- $p<\alpha$.

\section{c. Uji Independensi Residu}

Independensi residu atau autokorelasi residu dapat dilakukan menggunakan uji Ljung-Box [7]. Hipotesis dari uji Ljung-Box dapat dituliskan sebagai berikut :

i. Hipotesis

$$
H_{0}: \rho_{1}=\rho_{2}=\cdots=\rho_{m}=0 \text { (tidak terdapat autokorelasi pada residu sampai }
$$$$
\text { lag ke }-m \text { ) }
$$

$H_{1}$ :paling tidak terdapat satu $\rho_{i} \neq 0$ untuk $i=1,2,3, \ldots, m \quad$ (terdapat autokorelasi paling tidak pada satu lag)

ii. Tingkat signifikansi $=0,05$

iii. Daerah kritis

$$
H_{0} \text { ditolak jika } Q>\chi_{m}^{2} \text { atau } p-\text { value }<\alpha .
$$

\section{iv. Statistik uji}

$$
Q=T(T+2) \sum_{k=1}^{m} \frac{\widetilde{\rho}_{k}^{2}}{T-k}
$$

dengan

$T=$ jumlah data

$k=$ jumlah lag

$\widetilde{\rho}_{k}=$ autokorelasi sampel lag ke $-k$ dari $r_{t}$

$m=$ lag maksimum yang diuji

2.10. Peramalan. Jika model terbaik telah ditetapkan dan memenuhi uji diagnostik model maka model dapat digunakan untuk peramalan. Peramalan merupakan suatu proses yang berkelanjutan, maksudnya jika data terbaru muncul, model perlu diduga dan diperiksa kembali [10].

\section{Metodologi Penelitian}


Data yang penulis gunakan adalah data bulanan mengenai Tingkat Penghunian Tempat Tidur (TPTT) Hotel Bintang Tiga Kota Surakarta dari tahun 2007 hingga 2017 sebanyak 132 observasi. Data diperoleh dari Surakarta Dalam Angka 2007-2012, Figur Data Kota Surakarta Tahun 2017, dan Badan Pusat Statistik. Rata-rata tingkat penghunian tempat tidur hotel bintang tiga Kota Surakarta tahun 2007-2017 yaitu sebesar 56.372\%. Hal ini berarti rata-rata jumlah kamar yang dipakai setiap malam pada seluruh hotel bintang tiga tahun 2007-2017 adalah sebesar 56,372\%. Tingkat penghunian tempat tidur hotel bintang tiga Kota Surakarta terendah terjadi pada Februari 2007 sebesar 32.92\%. Sedangkan tingkat penghunian tempat tidur hotel bintang tiga Kota Surakarta tertinggi terjadi pada Desember 2017 sebesar 74.42\%. Hal ini disebabkan karena banyaknya event yang diselenggarakan di Kota Surakarta, salah satunya yaitu event Solo Market Mice yang mengundang beberapa agen travel dari kota-kota besar. Selain itu, banyaknya destinasi wisata di Kota Surakarta menyebabkan tingkat hunian hotel meningkat.

\section{Hasil dan Pembahasan}

Dalam bab ini dibahas terkait peramalan tingkat hunian tempat tidur hotel bintang tiga Kota Surakarta menggunakan ARIMA.

4.1. Pola Data. Sebelum dibentuk model dalam meramalkan tingkat hunian tempat tidur hotel bintang tiga Kota Surakarta, langkah awal yang perlu dilakukan yaitu menentukan pola data. Untuk menentukan pola data, dapat dilakukan dengan melihat plot data dan plot ACF. Plot data Tingkat Penghunian Tempat Tidur (TPTT) hotel bintang tiga Kota Surakarta dari tahun 2007 hingga 2017 ditampilkan pada Gambar 4.1.

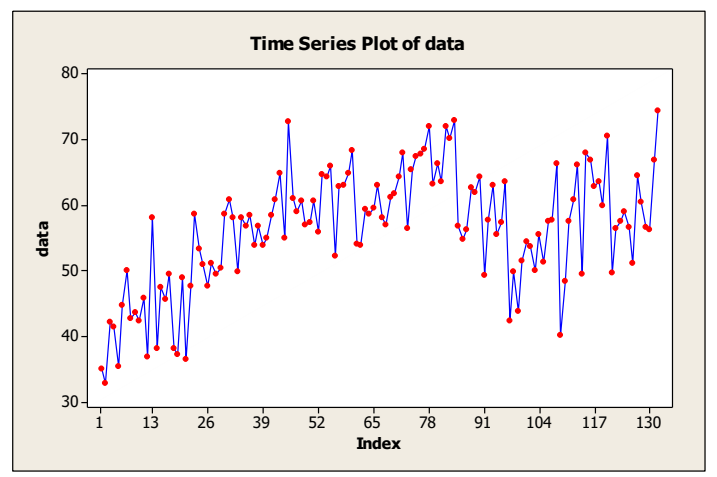

Gambar 4.1 Plot Data

Berdasarkan Gambar 4.1, terlihat bahwa data TPTT hotel bintang tiga Kota Surakarta tahun 2007-2017 cenderung mengalami kenaikan dari waktu ke waktu sehingga dapat dikatakan data berpola trend naik dan tidak memiliki rata-rata yang konstan. 
Plot ACF

Plot ACF dari data TPTT hotel berbintang tiga Kota Surakarta tahun 2007-2017 ditampilkan pada Gambar 4.2.

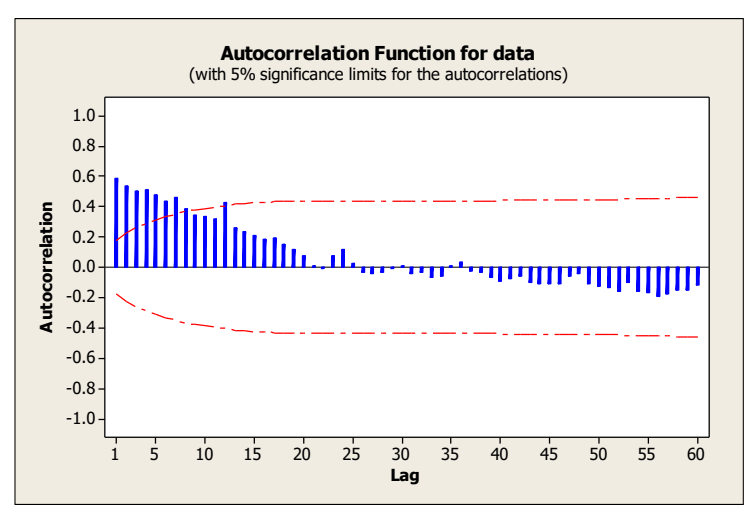

Gambar 4.2 Plot ACF

Berdasarkan Gambar 4.2, terlihat bahwa lag awal signifikan setelah itu turun secara perlahan menuju nol sehingga dapat dikatakan bahwa data TPTT hotel bintang tiga Kota Surakarta tahun 2007-2017 berpola trend.

Berdasarkan plot data dan plot ACF pada Gambar 4.1 dan 4.2, dapat disimpulkan bahwa data TPTT hotel bintang tiga Kota Surakarta tahun 2007-2017 cenderung berpola trend (tidak stasioner). Hal ini diperkuat dengan dilakukannya uji ADF pada data. Berdasarkan hasil uji ADF diperoleh nilai probabilitas yaitu 0.407 yang lebih besar dari tingkat signifikansi $\alpha=0.05$ sehingga dapat disimpulkan bahwa data TPTT hotel bintang tiga Kota Surakarta dari tahun 2007 hingga 2017 tidak stasioner.

4.2. Proses Pembedaan (Differencing) Data. Data TPTT hotel bintang tiga Kota Surakarta tahun 2007-2017 tidak stasioner sehingga perlu dilakukan pembedaan (differencing) pada data. Plot data hasil proses differencing disajikan pada Gambar 4.3.

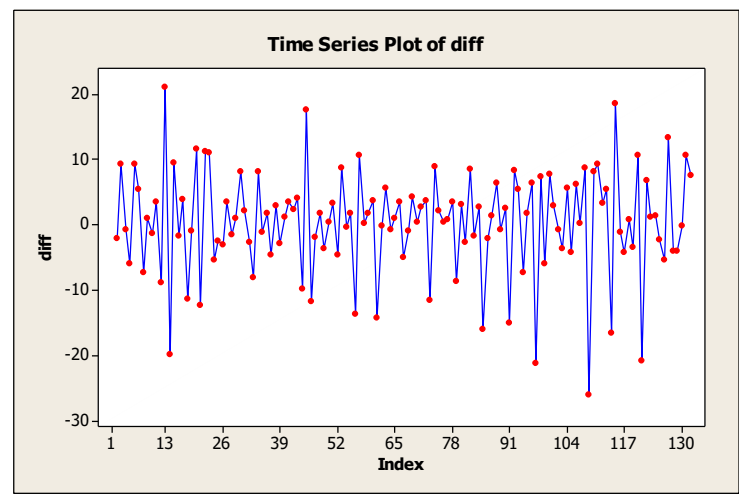

Gambar 4.3 Plot Data Setelah Differencing 
Berdasarkan Gambar 4.3, setelah dilakukan proses differencing data TPTT hotel bintang tiga Kota Surakarta tahun 2007-2017 telah stasioner. Berdasarkan hasil uji ADF diperoleh nilai probabilitas yaitu 0.01 lebih kecil dari tingkat signifikansi $\alpha=0.05$, artinya data TPTT hotel bintang tiga Kota Surakarta tahun 2007-2017 hasil proses differencing telah stasioner.

4.3. Identifikasi Model ARIMA. Setelah data TPTT hotel bintang tiga Kota Surakarta tahun 2007-2017 stasioner, maka dapat dimodelkan ke dalam model ARIMA. Plot ACF dan plot PACF hasil proses differencing dapat digunakan untuk mengidentifikasi orde tertinggi AR maupun MA. Plot ACF dan plot PACF hasil proses differencing disajikan pada Gambar 4.4 dan Gambar 4.5.

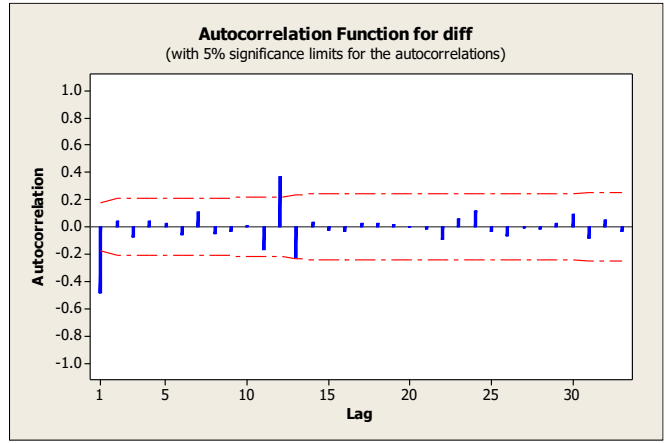

Gambar 4.4 Plot ACF Setelah

Differencing

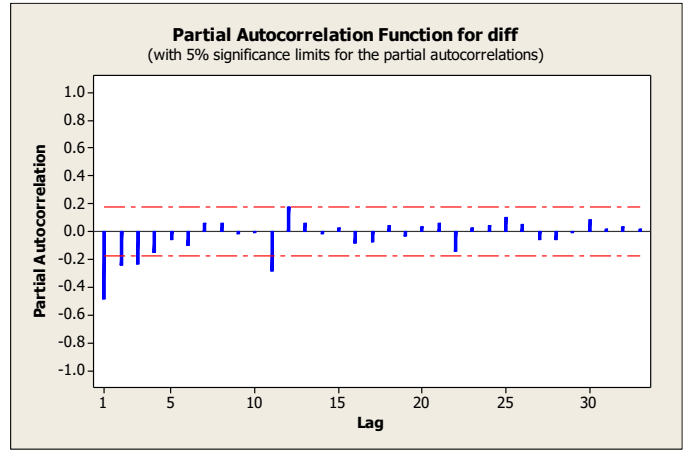

Gambar 4.5 Plot PACF Setelah

Differencing

Gambar 4.4 menunjukkan nilai ACF keluar dari pita konfidensi pada lag 1 kemudian terputus setelahnya. Sedangkan Gambar 4.5 menunjukkan nilai PACF keluar dari pita konfidensi pada lag 1,2, dan 3. Pada bagian sebelumnya, telah dilakukan differencing sebanyak satu kali, sehingga pilihan model yang dapat digunakan adalah IMA $(1,1)$, ARI $(1,1)$, ARIMA $(1,1,1)$, ARI $(2,1)$, ARIMA $(2,1,1)$, ARI $(3,1)$, dan ARIMA $(3,1,1)$.

4.4. Uji Signifikansi Parameter dan Konstanta. Uji signifikansi parameter dan konstanta dilakukan untuk mendapatkan model terbaik. Berdasarkan subbab 3.8, hasil uji signifikansi parameter dan konstanta model ditunjukkan pada Tabel 4.1.

Tabel 4.1 Hasil Uji Signifikansi Parameter dan Konstanta Model

\begin{tabular}{|l|l|l|l|l|}
\hline Model & Variabel & Koefisien & Probabilitas & Signifikansi \\
\hline IMA (1,1) & MA (1) & 0.7536 & 0.000 & Signifikan \\
& C & 0.1985 & 0.155 & Tidak \\
& & & & Signifikan \\
\hline
\end{tabular}




\begin{tabular}{|c|c|c|c|c|}
\hline$\overline{\mathrm{ARI}}(1,1)$ & $\begin{array}{l}\text { AR (1) } \\
\text { C }\end{array}$ & $\begin{array}{l}-0.4849 \\
0.4284\end{array}$ & $\begin{array}{l}0.000 \\
0.482\end{array}$ & $\begin{array}{l}\text { Signifikan } \\
\text { Tidak } \\
\text { Signifikan }\end{array}$ \\
\hline ARIMA $(1,1,1)$ & $\begin{array}{l}\text { AR (1) } \\
\text { MA (1) } \\
\text { C }\end{array}$ & $\begin{array}{l}-0.0095 \\
0.7496 \\
0.2010\end{array}$ & $\begin{array}{l}0.936 \\
0.000 \\
0.157\end{array}$ & $\begin{array}{l}\text { Tidak } \\
\text { Signifikan } \\
\text { Signifikan } \\
\text { Tidak } \\
\text { Signifikan }\end{array}$ \\
\hline ARI $(2,1)$ & $\begin{array}{l}\mathrm{AR}(1) \\
\mathrm{AR}(2) \\
\mathrm{C}\end{array}$ & $\begin{array}{l}-0.6152 \\
-0.2651 \\
0.4932\end{array}$ & $\begin{array}{l}0.000 \\
0.003 \\
0.404\end{array}$ & $\begin{array}{l}\text { Signifikan } \\
\text { Signifikan } \\
\text { Tidak } \\
\text { Signifikan }\end{array}$ \\
\hline ARIMA $(2,1,1)$ & $\begin{array}{l}\text { AR (1) } \\
\text { AR (2) } \\
\text { MA (1) } \\
\text { C }\end{array}$ & $\begin{array}{l}-1.2576 \\
-0.2653 \\
-0.9819 \\
0.755\end{array}$ & $\begin{array}{l}0.000 \\
0.001 \\
0.000 \\
0.545\end{array}$ & $\begin{array}{l}\text { Signifikan } \\
\text { Signifikan } \\
\text { Signifikan } \\
\text { Tidak } \\
\text { Signifikan }\end{array}$ \\
\hline ARI $(3,1)$ & $\begin{array}{l}\text { AR (1) } \\
\text { AR (2) } \\
\text { AR (3) } \\
\text { C }\end{array}$ & $\begin{array}{l}-0.6867 \\
-0.4344 \\
-0.2657 \\
0.5644\end{array}$ & $\begin{array}{l}0.000 \\
0.000 \\
0.003 \\
0.325\end{array}$ & $\begin{array}{l}\text { Signifikan } \\
\text { Signifikan } \\
\text { Signifikan } \\
\text { Tidak } \\
\text { Signifik } \\
\text { an }\end{array}$ \\
\hline ARIMA $(3,1,1)$ & $\begin{array}{l}\text { AR (1) } \\
\text { AR (2) } \\
\text { AR (3) } \\
\text { MA (1) }\end{array}$ & $\begin{array}{l}-1.5370 \\
-0.8480 \\
-0.2824 \\
-0.9212\end{array}$ & $\begin{array}{l}0.000 \\
0.000 \\
0.003 \\
0.003\end{array}$ & $\begin{array}{l}\text { Signifikan } \\
\text { Signifikan } \\
\text { Signifikan } \\
\text { Signifikan }\end{array}$ \\
\hline
\end{tabular}




\begin{tabular}{|l|l|l|l|l|}
\hline \hline & C & 0.957 & 0.400 & $\begin{array}{l}\text { Tidak } \\
\text { Signifikan }\end{array}$ \\
\hline
\end{tabular}

Berdasarkan Tabel 4.1, model ARIMA $(1,1,1)$ mempunyai parameter pada AR (1) yang tidak signifikan, ditandai dengan nilai- $p>0.05$ sehingga model ini tidak dipilih. Model IMA $(1,1)$, ARI $(1,1)$, ARI $(2,1)$, ARIMA $(2,1,1)$, ARI $(3,1)$, dan ARIMA $(3,1,1)$ mempunyai parameter yang signifikan akan tetapi konstanta tidak signifikan sehingga konstanta dikeluarkan dari model dan dilakukan kembali uji signifikansi parameter tanpa melibatkan konstanta. Hasil uji signifikansi parameter disajikan dalam Tabel 4.2.

Tabel 4.2 Hasil Uji Signifikansi Parameter Tanpa Melibatkan Konstanta

\begin{tabular}{llccl}
\hline Model & Variabel & Koefisien & Probabilitas & Signifikansi \\
\hline IMA & MA (1) & 0.7361 & 0.000 & Signifikan \\
$(1,1)$ & & & & \\
\hline ARI & AR (1) & -0.4831 & 0.000 & Signifikan \\
$(1,1)$ & & & & \\
\hline ARI & AR (1) & -0.6117 & 0.000 & Signifikan \\
$(2,1)$ & AR (2) & -0.2623 & 0.003 & Signifikan \\
& & & & \\
\hline ARIMA & AR (1) & -1.2643 & 0.000 & Signifikan \\
$(2,1,1)$ & AR (2) & -0.2729 & 0.001 & Signifikan \\
& MA (1) & -0.9801 & 0.000 & Signifikan \\
\hline ARI & AR (1) & -0.6820 & 0.000 & Signifikan \\
$(3,1)$ & AR (2) & -0.4929 & 0.000 & Signifikan \\
& AR (3) & -0.2622 & 0.003 & Signifikan \\
\hline ARIMA & AR (1) & -1.5598 & 0.000 & Signifikan \\
$(3,1,1)$ & AR (2) & -0.8430 & 0.000 & Signifikan \\
& AR (3) & -0.2672 & 0.003 & Signifikan \\
& MA (1) & -0.9470 & 0.000 & Signifikan \\
\hline
\end{tabular}

Berdasarkan Tabel 4.2, model yang akan dipilih yaitu IMA (1,1), ARI (1,1), ARI $(2,1)$, ARIMA $(2,1,1)$, ARI $(3,1)$, dan ARIMA $(3,1,1)$ karena parameter signifikan dengan ditandai nilai- $p<0.05$. Selanjutnya untuk mengetahui model mana yang paling cocok untuk meramalkan, maka dipilih model yang mempunyai nilai MSE terkecil. 
Perbandingan nilai MSE dari model yang mempunyai parameter signifikan disajikan dalam Tabel 4.3.

Tabel 4.3 Perbandingan Nilai MSE

\begin{tabular}{ll}
\hline \multicolumn{1}{c}{ Model } & MSE \\
\hline IMA $(1,1)$ & 40.70 \\
\hline ARI $(1,1)$ & 48.07 \\
\hline ARI $(2,1)$ & 45.27 \\
\hline ARIMA $(2,1,1)$ & 51.24 \\
\hline ARI $(3,1)$ & 42.67 \\
\hline ARIMA $(3,1,1)$ & 45.54 \\
\hline
\end{tabular}

Berdasarkan Tabel 4.3, model yang dipilih adalah model IMA $(1,1)$.

4.5. Uji Diagnostik Model. Setelah dilakukan pemilihan model terbaik, langkah selanjutnya adalah menguji diagnostik model yang telah dipilih yaitu IMA $(1,1)$.

4.5.1. Uji Normalitas

i. Hipotesis

$H_{0}$ : Residu berdistribusi normal

$H_{1}$ : Residu tidak berdistribusi normal

ii. Tingkat Signifikansi : $\alpha=0.05$

iii. Keputusan uji

$H_{0}$ ditolak jika $p$ value $<\alpha=0.05$

iv. Statistik uji : berdasarkan output, diperoleh nilai $p$-value sebesar 0.8271

v. Kesimpulan : karena nilai- $p=0.8271>0.05$ maka $H_{0}$ tidak ditolak artinya residu berdistribusi normal.

4.5.2. Uji Indenpendensi

i. Hipotesis

$H_{0}$ : Tidak terdapat autokorelasi di dalam residu

$H_{1}$ : Terdapat autokorelasi di dalam residu

Tingkat Signifikansi : $\alpha=0.05$

ii. Keputusan uji : $H_{0}$ ditolak jika nilai- $p<\alpha=0.05$

iii. Statistik uji : berdasarkan output, diperoleh nilai- $p$ sebesar 0.06338

iv. Kesimpulan : karena nilai- $p=0.06338>0.05$ maka $H_{0}$ tidak ditolak artinya tidak terdapat autokorelasi di dalam residu. 


\subsubsection{Uji Homoskedastisitas}

i. Hipotesis

$H_{0}$ : Tidak terdapat heterogenitas di dalam residu

$H_{1}$ : Terdapat heterogenitas di dalam residu

ii. Tingkat Signifikansi : $\alpha=0.05$

iii. Keputusan uji : $H_{0}$ ditolak jika nilai- $p<\alpha=0.05$

iv. Statistik uji : berdasarkan output, diperoleh nilai- $p$ sebesar 0.0732

v. Kesimpulan : karena nilai $-p=0.0732>0.05$ maka $H_{0}$ tidak ditolak artinya tidak terdapat heterogenitas di dalam residu. Residu dari model $\operatorname{IMA}(1,1)$ telah memenuhi asumsi normalitas, independensi, dan homoskedastisitas. Oleh karena itu model IMA $(1,1)$ baik digunakan untuk meramalkan data TPTT Hotel Bintang Tiga Kota Surakarta.

\subsection{Peramalan Tingkat Hunian Tempat Tidur Hotel Bintang Tiga Kota}

Surakarta. Hasil peramalan tingkat hunian tempat tidur hotel bintang tiga Kota Surakarta dengan model IMA $(1,1)$ selama lima bulan ke depan disajikan dalam tabel 4.4.

Tabel 4.4 Hasil Peramalan Tingkat Hunian Tempat Tidur Hotel Bintang Tiga Kota

Surakarta

\begin{tabular}{llll}
\hline \multirow{2}{*}{ Periode } & \multirow{2}{*}{ Forecast } & \multicolumn{2}{l}{ Batas Interval Konfidensi 95\% } \\
\cline { 3 - 4 } & & Bawah & Atas \\
\hline Januari 2018 & 64.4625 & 51.9964 & 76.9286 \\
\hline Februari 2018 & 64.6610 & 51.8221 & 77.5000 \\
\hline Maret 2018 & 64.8596 & 51.6584 & 78.0608 \\
\hline April 2018 & 65.0581 & 51.5043 & 78.6119 \\
\hline Mei 2018 & 65.2566 & 51.3592 & 79.1541 \\
\hline
\end{tabular}

Berdasarkan Tabel 4.7, hasil peramalan tingkat hunian tempat tidur hotel bintang tiga Kota Surakarta dengan model IMA $(1,1)$ meningkat per bulan untuk lima bulan ke depan yaitu Januari 2018 sampai dengan Mei 2018. Plot peramalan tingkat hunian tempat tidur hotel bintang tiga Kota Surakarta disajikan dalam Gambar 4.6. 


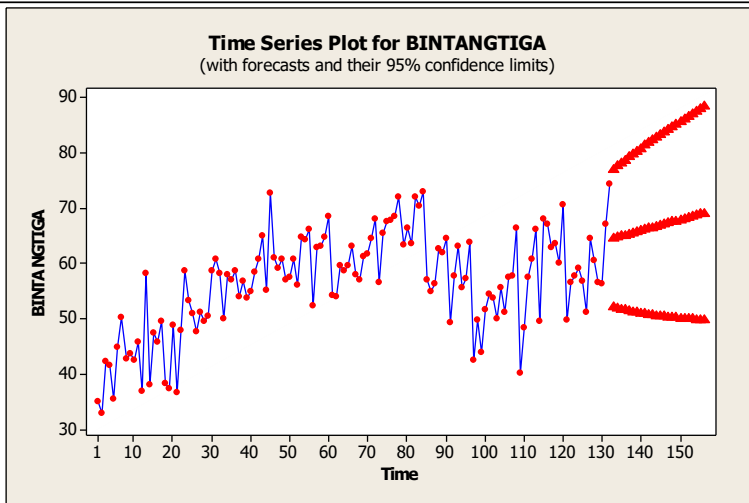

Gambar 4.6 Plot Peramalan Tingkat Hunian Tempat Tidur Hotel Bintang Tiga

Kota Surakarta

\section{Kesimpulan}

Berdasarkan hasil dan pembahasan diperoleh kesimpulan sebagai berikut:

1. Model yang paling baik untuk meramalkan tingkat hunian tempat tidur hotel bintang tiga Kota Surakarta adalah IMA $(1,1)$ dengan Mean Square Error (MSE) sebesar 40.70 .

2. Hasil peramalan tingkat hunian tempat tidur hotel bintang tiga Kota Surakarta untuk bulan Januari 2018 hingga bulan Mei 2018, mengalami peningkatan setiap bulannya.

\section{Daftar Pustaka}

[1] Badan Pusat Statistik. Kota Surakarta Dalam Angka 2007-2012. https://surakartakota.bps.go.id/ , diakses pada 14 Februari 2019. 2007-2012.

[2] Utama, I.G.B.R. Pengantar Industri Pariwisata. Yogyakarta: CV. BUDI UTAMA. 2015.

[3] Sugiarto, E. Hotel Front Office Administration. Jakarta: Gramedia Pustaka Utama. 1996.

[4] Arsyad, Lincolin. Peramalan Bisnis. Jakarta: Ghalia Indonesia. 1995.

[5] Makridakis, S., dkk. Metode dan Aplikasi Peramalan. Jakarta: Erlangga. 1999.

[6] Hanke, J.E. \& Winchern, D.W. Business Forecasting. New Jersey: Cliffs Prentice Hall. 2005.

[7] Tsay, R.S. Analysis of Financial Time Series. USA: John Wiley and Sons Inc. 2005

[8] Cryer, J.D. Time Series Analysis. New York: Springer Science + Business Media. 2008.

[9] Engle, R.F. Autoregressive Conditional Heteroscedasticity with Estimates of the Variance of United Kingdom Inflation. Econometrica, 50, 987-1008. 1982.

[10] Mulyono. Peramalan Harga Saham dan Nilai Tukar: Teknik Box-Jenkins. Ekonomi dan Keuangan Indonesia, XLVIII. 2000. 